\title{
THE REORIENTATION OF FRENCH SOCIALISM, I888-90
}

Historians are in general agreement that French socialism experienced a major reorientation at the end of the 1880's and the beginning of the 1890's. In 1888 the French socialist movement consisted of several diminutive and poorly organized factions, which could not claim, either singly or collectively, a significant national following despite nearly a decade of organizing and propagandizing. Yet by 1893 socialists were able to elect some forty deputies to the Chamber of Deputies, and in the previous year scored numerous victories in municipal elections. Electorally impotent in the 1880's, socialists became a serious force in national political life with the victories of 1893. Nearly simultaneously, the stalemate among rival factions was broken as schism in the ranks of both Possibilists and Blanquists permitted the Guesdists to emerge as the dominant organization. Finally, these years were marked by the appearance of a pragmatic, reformist socialism most clearly evident in the new moderation of the Guesdists and the rise of the Independent Socialists.

While there is little dispute as to what occurred, explanations of why it took place have been less satisfactory. A persistent mode of analysis is that which sees the transformation as the result of a process of maturation. The "youthful" revolutionism and factionalism of the 1880 's gave way to the more moderate and responsible behavior of the 1890 's as socialism "came of age". As support grew and leaders were elected to public office, socialists became less shrill and strident, less ideological and more pragmatic. ${ }^{1}$ A slightly different version characterizes the process as one of "embourgeoisement", in which both the social composition of the supporters and the attitudes of the leadership were affected. Party leaders, so the argument goes, anxious to gain

1 This is the view taken of the Guesdists by Claude Willard in Le Mouvement socialiste en France (1893-1905): les Guesdistes (Paris, 1965), see chapters IV and V, especially pp. 90-91. Aaron Noland, The Founding of the French Socialist Party (1893-1905) (Cambridge, Mass., 1956), p. 33, employs the same metaphor when he speaks of the party's coming of age in 1893. 
and hold public office, sought to broaden their constituencies by drawing new voters and party members from the ranks of the petty bourgeoisie rather than the proletariat. And increases in strength and influence brought "respectability" to party leaders. ${ }^{1}$

Both these approaches to the problem of the reorientation of socialist politics offer some insight, but they share the difficulty that they are definitions of what took place rather than explanations of it. Political movements may indeed change as they mature, but the metaphor from personal development does not explain either the timing or the extent of the transformation. Secondly, while some ambitious and successful socialist politicians tended to neglect their party responsibilities and lose sight of ultimate goals in pursuit of electoral success, all socialist politicians did not follow this course, as is demonstrated by the fights that took place in the early 1890's. Neither of these approaches provides an explanation in concrete terms of the process by which the reorientation was accomplished.

What is here argued is that a sequence of political events taking place between 1888 and 1890 changed the relative positions of the rival socialist factions, and that the cumulative effect of these changes, compressed as they were within a brief two-year span, brought about major changes in French socialism, fully apparent only after the elections of 1893. In 1888 the socialist movement faced a serious crisis; socialist leaders of the various factions were aware of their predicament and searching for means of escape when the Boulanger Crisis broke. The Crisis acted as a catalyst, forcing issues into the open and precipitating the changes that took place. The configuration of sectarian rivalries that had dominated the French socialist movement of the 1880 's was shattered, and the way opened for a general realignment of forces and the growth of the French socialist movement. Crucial to an understanding of the entire process is the recognition of the relationships among the various socialist groups and how they were affected by developments of the period. Despite the appearance recently of several valuable studies of one or another group or region, ${ }^{2}$ there has

1 The classic formulation is that of Robert Michels, Political Parties, transl. by Eden and Cedar Paul (New York, 1959), especially Part Four, ch. III. While Michels is of course speaking of the situation in the German Social Democratic Party, the same sort of thing was said of French socialists. It was a prominent feature of the Anarcho-syndicalist criticism of socialists.

2 Since the publication in 1965 of Willard's massive volume on the Guesdists, a number of valuable studies have appeared. David Stafford's From Anarchism to Reformism (Toronto, 1971) contributes much to our knowledge of Paul Brousse and Possibilism. Of numerous articles that have appeared, the following are particularly helpful: Robert P. Baker, "Socialism in the Nord, 1880-1914", in: International Review of Social History, XII (1967), pP. 357-89; Patrick 
been little effort to correlate developments specific to one faction or area into a picture of the movement as a whole.

Divided into warring factions since 1882 , leaders of the two major factions, the Possibilists of the Fédération des travailleurs socialistes de France and the Guesdists of the Parti ouvrier, had grown accustomed to mutual recrimination. A third group, the Blanquists of the Comite révolutionnaire central, dated from 1881, but it had not been involved in the quarrels that led to the split between the Guesdists and the Possibilists. ${ }^{1}$ The Guesdists thought of themselves as the "instructors and recruiters" of the working class, seeking to organize it and develop its class consciousness. ${ }^{2}$ Essentially Marxian in their orientation, they rejected the view that the workers' lot could be improved by partial and gradual reforms. For this reason they attached little importance to electoral politics; election campaigns offered one opportunity among others to propagandize and develop support, but electing a few socialists to the Chamber of Deputies or to municipal councils was not the route to the "conquest of political power", of which the Guesdists frequently spoke. Instead they emphasized the need to develop a strong and disciplined organization as the necessary pre-condition of the overthrow of the bourgeois order. The Possibilists, as their name implies, rejected what Paul Brousse once called this "all or nothing" policy of the Guesdists in favor of a more gradualist transition to socialism. ${ }^{3}$ Brousse developed a theory of "public services", in which he held that an evolution from private enterprise to public service would occur naturally as the economy developed. ${ }^{4}$ This doctrine became the foundation of the "gas and water" municipal socialism

H. Hutton, "The Impact of the Boulangist Crisis Upon the Guesdist Party at Bordeaux", in: French Historical Studies, VII (1971), pp. 226-44; idem, "The Role of the Blanquist Party in Left-wing Politics in France, 1879-90", in: Journal of Modern History, XLVI (1974), pp. 277-95; Yves Lequin, "Classe ouvrière et idéologie dans la région Lyonnaise à la fin du XIXe siècle", in: Le Mouvement Social, No 69 (1969), pp. 3-20; M. Winock, "La Naissance du parti 'allemaniste' (1890-91)", ibid., No 75 (1971), pp. 31-62.

1 Numerous general histories of French socialism deal with this period. One of the best brief accounts is Georges Lefranc, Le Mouvement socialiste sous la Troisième République (Paris, 1963), chs II and III.

2 The phrase quoted is from Willard, Le Mouvement socialiste, p. 27. Willard's coverage on the character of Guesdist activity in the 1880's is brief but excellent.

${ }^{3}$ Le Prolétaire, 18 November 1881.

4 Paul Brousse, La Propriété collective et les services publics (Paris, 1883), passim. This pamphlet of thirty-five pages is the most complete formulation of the theory Brousse ever published. 
Parisian Possibilists, several of whom were elected to the Paris municipal council, espoused by the end of the 1880's. Possibilist opposition to Guesdist "authoritarianism", which can be traced back to the quarrels in the First International between Marxists and Anarchists, led the Fédération des travailleurs to allow wide autonomy to local groups and to permit considerable doctrinal latitude.

Neither the Guesdists nor the Possibilists succeeded in creating a well-articulated organization. Both had provided fairly elaborate organizational schemes for their parties, complete with regional federations, regional and national congresses and national councils. But much of this apparatus was a dead letter from the outset or soon atrophied. Party congresses were held irregularly - the Guesdists had none between 1884 and 1890 , and the Possibilists had none in 1885, 1886 , or 1889 . Likewise, regional federations played an insignificant role in socialist affairs. An examination of the Possibilist press reveals the growing paralysis of Possibilist federations in the second half of the decade: the West Federation was reduced to only about a dozen groups by 1886, and in the following year it declared an amnesty on arrears in dues in an attempt to revive the organizations. Possibilists were unable to create federations in the North or Midi, and the one for the East simply disappeared in $1885 .^{1}$ Possibilism's one solidly organized and active regional federation was the Paris-based Union fédérative $d u$ Centre. The Guesdists, for all their emphasis on "organization and discipline", were not much better off than the Possibilists. The Parti ouvrier consisted of a hodgepodge of local groups that lacked departmental or regional consolidation before the end of the 1880's. Yet the Guesdists, in contrast to the Possibilists, made a sustained effort to recruit provincial support. Party leaders, especially Guesde, made numerous provincial tours speaking and organizing. According to his biographer, Guesde held more than 1,200 meetings between 1882 and 1890, the great majority of them outside Paris. ${ }^{2}$ By 1888 the Guesdists had made some gains in the provinces and were optimistic about future possibilities, in spite of the fact that they could not develop support in Paris. "The situation is shaping up well", Paul Lafargue exulted to Engels; "I have never had such confidence in the movement."3

The third of the organized groups of the 1880's, the Comité revo-

1 Le Prolétariat, 2 January 1886 and 28 May 1887. Le Prolétariat was the successor to Le Prolétaire as the official journal of the Possibilists.

2 Adéodat Compère-Morel, Jules Guesde, le socialisme fait homme (Paris, 1937), p. 258 .

${ }^{3}$ Friedrich Engels, Paul et Laura Lafargue, Correspondance (3 vols; Paris, 1956-59), II, p. 138. Hereafter cited as Correspondance. 
lutionnaire central, is difficult to discuss in the same way as the Guesdists and the Possibilists, for the Blanquists were not a political party in the same sense. The origin of the Comite is in itself suggestive of the difference. After Blanqui's death in January 1881, a movement was launched to provide a monument to his memory. Out of this effort came the CRC, not a party really, although one of its purposes was "to profit from the election period". The Comité was to consist of two representatives from each arrondissement of Paris and each of several suburban districts. There were to be no federations, congresses or programs. The organization was to remain covert. ${ }^{1}$ The Comite kept alive, and in turn was sustained by, the traditions of the Commune and the insurrectionist politics of Blanqui. The most prominent leaders, Emile Eudes, Edouard Vaillant and Ernest Granger, were well-known Communards; their greatest strength came from the old red quarters of Paris; and they celebrated the simplicity and directness of the popular politics of the Commune.

"Là, il n'y avait pas de questions compliquées à compartiments, de programmes à discuter. La question était simple: la Commune et Versailles, le proscrit, le forçat en face des bourreaux, le prolétariat devant la bourgeoisie, la révolution devant la réaction."2

This statement made in 1881 by Vaillant is not an inaccurate reflection of the Blanquists' orientation in the 1880's, but the brand of spontaneous popular politics it reflects is lacking in direction and as ambiguous as the Communard tradition that Blanquism preserved.

To identify, as has been done above, each of these major groups in terms of the positions articulated by a few leaders misrepresents the degree of coherence within each. Evidence abounds to show that local socialist militants were uninterested in and sometimes confused by the disputes among national leaders. As a case in point, several local Possibilist groups from the Midi voted to place Guesde and his close associate Gabriel Deville on the National Council of the Fédération des travailleurs two years after the schism between Guesdists and Possibilists. ${ }^{3}$ In Lyon, Guesdists and Blanquists worked together closely and it is difficult to distinguish between them. ${ }^{4}$ In Marseille socialists of

1 For the Blanquists see Charles Da Costa, Les Blanquistes (Paris, 1912); Maurice Dommanget, Edouard Vaillant (Paris, 1956); and Hutton, "The Role of the Blanquist Party", loc. cit.

${ }^{2}$ Ni Dieu, Ni Maître, 16 January 1881.

${ }^{3}$ Le Prolétaire, 2 February 1884.

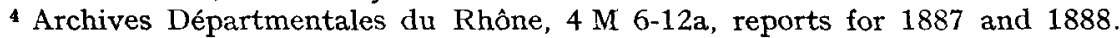
Departmental archives will hereafter be cited as AD, followed by the name of the department. 
many colorations cohabited in a Union socialiste révolutionnaire. ${ }^{1}$ There were, of course, areas in the provinces where loyalties were clearly defined: Guesdists dominated in the Nord and the Allier; Possibilists in the Ardennes; Blanquists in the Cher. But these loyalties sometimes bore less relationship to differences of doctrine and practice among factions than to circumstances surrounding the earliest socialist activity in the area. Guesdist strength in the Allier dated from the early 1880's, when Guesde and Lafargue made a speaking tour of the department that led them and a local leader, Jean Dormoy, to be arrested. The strength of Blanquism in the Cher was not coincidental: Vaillant was from the department and maintained a home at Vierzon. The Possibilists' strength in the Ardennes was largely the result of the efforts of one individual, J.-B. Clément. All of this is not to suggest that there were not real differences between groups or that conscious choice on the basis of those differences was not made by some. It is to say that there were other factors at work in determining the loyalties of local socialist groups and that lines demarcating factions were fuzzy.

No socialist group had significant electoral strength in the 1880's. The legislative elections of 1885 , the first the socialists were able to contest in any serious way, were conducted on the basis of departmental lists, which worked to the disadvantage of small parties lacking the resources to mount department-wide campaigns. In a few departments socialist lists made respectable showings, but only a handful of candidates who appeared as coalition candidates on Republican lists were elected. Even allowing for the unfavorable system of departmental lists, socialist leaders rightly viewed the election results with dismay. ${ }^{2}$ Things improved slightly in the municipal elections, held in Paris in 1887 and in the rest of France in the following year. In 1887 the Possibilists elected nine candidates to the Paris city council and the Blanquist Vaillant (who had first been elected in 1884) retained his seat. ${ }^{3}$ In 1888 the Guesdists scored victories in the provinces, notably in the departments of Nord and Allier. ${ }^{4}$ But these slight gains do not alter the basic pattern, common to all factions, of weakness at the polls.

Despite the Possibilist electoral victories in Paris, or perhaps because of them, the party faced some serious problems in the last years of the 1880 's. By concentrating their efforts on the capital to the increasing

${ }^{1}$ Le Travailleur (Marseille), 12 May and 7 July 1888; AD Bouches-du-Rhône, M 63392.

${ }^{2}$ Correspondance, I, pp. 308-09, where Lafargue declared that socialists had not anticipated "such a shameful defeat".

3 Le Prolétariat, 14 and 21 May 1887; Correspondance, II, pp. 38-39.

4 Le Cri du Travailleur (Lille), 12 May 1888. 
neglect of the provinces, the Possibilists were becoming a head without a body. Direction of the party had passed largely into the hands of the moderate wing headed by Brousse and other leaders who sat on the Paris municipal council. Increasingly they ignored national affairs to pursue within the city council Brousse's version of municipal socialism. As elective office holders (élus), they acquired a status independent of the party and became less attentive to its needs. By 1888 an opposing faction began to coalesce around Jean Allemane. It objected to the course the Possibilist moderates were following and called for renewed attention to development of party organization, especially in the provinces, and greater militancy. The ouvriériste theme of distrust of "politicians" was clearly present. ${ }^{1}$

Similarly, although the Guesdists could point to signs of increased strength, they faced two serious difficulties. The most important sign of strength was the increased and more widely distributed party membership produced by Guesdist organizational labors. But this strength was in the provinces, and the failure to develop a strong following in the Paris region deprived the Paris-based national leadership of close connection with rank-and-file followers. It also meant that the Guesdists lacked a national voice, as was reflected in the party's difficulty in maintaining an official newspaper in Paris even on a weekly basis, a function that the ephemeral provincial journals could not fill. ${ }^{2}$ The second problem lay in the party's continuing weakness at the polls. Somewhat ironically, the party that laid greatest stress on the conquest of political power as the means of proletarian emancipation was unable to conquer political power in the limited sense of getting candidates elected. From an ideological point of view neither of these weaknesses was particularly serious - Paris was less "proletarian" than the industrial North and, as the leaders continued to maintain, limited electoral success would not yield significant social change. But from the political point of view, these problems were serious, for they combined to mute the voice of the party and to diminish its influence, a circumstance, moreover, that

1 Archives de la Préfecture de Police, B A/1479 (reports of 21 July 1887 and 5 July 1888), hereafter cited as APP; Le Prolétariat, 25 June 1887; Winock, "Naissance du parti 'allemaniste"", loc. cit., pp. 35-36.

2 This is not the place to detail the difficulties of the Guesdists in maintaining a regular periodic press. Provincial journals came and went with amazing rapidity. In the Nord, for example, the journal Le Forçat, which survived for only one year (July 1883 to July 1884), was replaced by La Revanche du Forçat (nine numbers), then Le Cri du Forçat (eighteen numbers), and so on. In Paris the party launched an official organ, Le Socialiste, in 1885, but publication was interrupted in 1887 for over two months and after February 1888 it did not appear again until September 1890. 
had direct bearing on the party's principal task of organizing and educating the proletariat. This problem of political weakness was regarded as serious by many party leaders, some of whom were beginning to have doubts about Guesdist tactics. ${ }^{1}$

Finally, internal tensions began to emerge among the Blanquists. Vaillant, who had studied in Germany and spent his years of exile after the Commune in London where he became acquainted with Marx, wished to cast aside some of the more conspiratorial aspects of Blanquism and convert the CRC into a more open socialist party. Vaillant was on good terms personally with the Guesdists and advocated greater cooperation between the CRC and the Parti ouvrier. ${ }^{2}$ However, Vaillant's position was not shared by other Blanquist leaders, notably Granger. After Eudes's death in August 1888, the conflict between Vaillant and Granger involving the future direction of the CRC became serious. ${ }^{3}$

Thus the situation in the French socialist movement was much more fluid and uncertain at the end of the 1880's than has sometimes been supposed. Each of the three factions was loosely organized and in a state of uncertainty as to its future course. In fact, each had arrived at an impasse. This was of particular importance for the two larger groups, the Possibilists and the Guesdists. In their rivalry since 1882 each had claimed to be in possession of a formula - a combination of doctrine and practice - upon which a viable socialist politics could be built. The conceptions were mutually antagonistic and it had been assumed that one conception or the other, one party or the other, would prevail. But in 1888 such a resolution of their rivalry seemed more remote than ever. The search for ways to break out of the impasse coincided with the Boulanger crisis.

\section{II}

General Boulanger's mercurial career has been too frequently recounted to need recapitulation here. ${ }^{4}$ By the spring of 1888 Boulanger stood at the head of a protest movement of ambiguous purpose and diverse

1 This was true of both Gabriel Deville and Paul Lafargue, Guesde's principal lieutenants. Further discussion of this point appears below.

2 For the growing cooperation between Vaillant and the Guesdists see Correspondance, II, pp. 7-195, which cover the years 1887 and 1888 , especially pp. $182-83$.

3 Hutton, "The Role of the Blanquist Party", p. 292; Correspondance, II, p. 190; and APP, B A/497, which contains an interesting report on the "Attitude des socialistes devant le mouvement boulangiste", dated November 1888 . 4 The best account is that of Frederick $H$. Seager, The Boulanger Affair: Political Crossroad of France, 1886-1889 (Ithaca, N.Y., 1969). 
support, in which the common element was disillusionment with a seemingly corrupt and ineffectual regime. Much of Boulanger's initial support came from the Left, and the full extent of his collaboration with the Right was not revealed until after the crisis had passed. This leftist, popular element of the Boulangist movement must be kept in mind as we examine the response of the socialists to it.

Initially, the Possibilists were less divided over Boulanger than either the Guesdists or the Blanquists. Their basic position was formulated by Brousse in the spring of 1888. Brousse recognized Boulanger's disparate following and his lack of a clearly defined program, but concluded that the General posed a serious threat to the Republic. On that account he called for the creation of a broad antiBoulangist coalition that would ally socialists and republicans, "le concert de tous les membres dévoués de la grande famille républicaine". "Après tout", he declared, "[...] nous sommes, à titres divers, les fils de la Révolution française." Brousse spoke of a temporary coalition only: "La besogne commune d'assainissement accomplie, nous séparerons de nouveau [...] et nous retournerons les uns et les autres à nos affaires."1 But it seems likely that he also saw here an opportunity to develop a rapport with left republicans that would be more than temporary. At any rate, the Possibilists soon moved in the direction advocated by Brousse. With Jules Joffrin and Jean Allemane taking the lead, they combined in 1888 with Radicals to create a Sociéte des droits de l'homme et du citoyen, whose purpose was to rally support on the Left against the General. ${ }^{2}$ The active participation of Possibilists in the Sociéte produced accusations that the leaders were abandoning socialist principles in order to advance their personal political careers. As a result of these objections a motion was passed by the Union fédérative $d u$ Centre requesting party members to withdraw from the Société, which they did without objection in August. ${ }^{3}$ However, the essential position of republican concentration against Boulanger was maintained by the Possibilists through the legislative elections of September-October 1889, although elements in the party remained unconvinced of its wisdom and criticized the leadership on this issue. ${ }^{4}$

The Guesdist policy was abstentionism. It was formulated in April 1888, during one of Boulanger's early by-election campaigns in the Nord. The Lille section of the party declared that it would not take

${ }^{1}$ Le Prolétariat, 21 April and 12 May 1888. Quotations are from the number of 12 May.

2 Seager, The Boulanger Affair, pp. 159-62.

3 APP, B A/201 (report of 22 June 1888) and A/497 (report of November 1888).

4 Stafford, From Anarchism to Reformism, pp. 233-34. 
part in a contest that "could not in any way change the political situation of the country", 1 preferring to conserve its resources for the up-coming municipal elections (this itself an interesting anticipation of the change in the party's priorities). The Guesdists recommended to workers that they either vote for Boulanger's horse Tunis or write in the mot de Cambronne. ${ }^{2}$ Guesde himself first expressed his views at the time of this by-election. The Boulangist danger was real, he declared, but it had been produced entirely in reaction against the present government. The Parti ouvrier had better things to do than pull the chestnuts out of the fire for the bourgeois republic. Boulanger, on the other hand, simply exploited the discontent and offered the workers nothing. Boulangists and anti-Boulangists were two factions of the bourgeoisie between which the Parti ouvrier could not and would not choose. The task of the party was to close ranks and consolidate its strength in order to exploit the present disorder in the bourgeois camp. ${ }^{3}$ This "ni Ferry, ni Boulanger" position, developed by Guesde at an early stage of the crisis, was largely deduced from a traditional definition of the party's role in the politics of the Republic and not based on any very serious analysis of the Boulangist movement and the existing political situation. ${ }^{4}$ It was proper, from a doctrinal point of view. Others in the party, however, saw Guesde's propriety as a luxury the party could not afford and called for a bolder policy.

Lafargue and Raymond Lavigne, the Parti ouvrier's able leader in the Bordeaux region, both arrived at the conclusion, evidently independently, that the Parti ouvrier could benefit from greater cooperation with the Boulangists than Guesde's formula allowed. Lafargue's flirtation with Boulangism is familiar and can be most readily followed in his correspondence with Engels. ${ }^{5}$ In Lafargue's analysis the large element of social discontent in the Boulangist movement "could assume a socialist form if allowed freely to develop." Moreover, he believed the crisis had produced a political shift in which the Radicals, by allying with the Republicans against Boulanger, had abandoned their status as an opposition party to become part of the governing coalition. This would permit the mantle of "radical opposition" to fall to the Boulangists and their allies on the left, a

${ }^{1}$ Le Cri du Travailleur, 7 April 1888.

2 Ibid., 14 April 1888.

3 Ibid., 7 April 1888.

"The formula "neither Ferry, nor Boulanger", or sometimes "neither plague, nor cholera", was often repeated from this point forward. But even when his position was challenged from within the party, Guesde did not elaborate.

5 See Correspondance, II, pp. 113-341, covering the period from March 1888 to October 1889.

- Ibid., p. 138. 
prospect that suggested to him a coalition between the Parti ouvrier and the Boulangists for the coming legislative elections, unless the Boulangists were to "go over to the Bonapartists and the monarchists".1 Lafargue believed the party could gain nothing by maintaining its independent stance; it simply was not strong enough to "show that there is a real third issue besides this pretended dilemma", as recommended by Engels and implied in Guesde's position. ${ }^{2}$ At the same time, to adopt a strong anti-Boulangist position would drive the party into an alliance with the Radicals. It "would be uselessly compromised, as the Possibilists have been, without achieving any result". 3

Lafargue's running commentary did not lead to a reversal of the general policy established by Guesde; he seems to have chosen not to make a serious issue of the matter. ${ }^{4}$ However, in Bordeaux Lavigne carried the local Guesdists into open alliance with the Boulangists. ${ }^{5}$ Labor unrest and popular hostility to the Opportunists who dominated local politics helped to produce working-class enthusiasm for Boulanger, which was in evidence as early as the summer of $1887 . .^{6} \mathrm{Lavigne}$ encouraged the tendency then, and throughout 1888, although there was no alliance between the Guesdists and Boulangists in this period.? Sometime between December 1888 and January 1889, when Guesde was in the seaside town of Arcachon near Bordeaux seeking to recover from a respiratory ailment, he appears to have met with local party leaders in Bordeaux in an attempt to dissuade them from an alliance with the Boulangists. ${ }^{8}$ This proved to be of no avail, and, after the crucial Paris by-election of 27 January, 1889, which marked the apogee of the Boulangist movement, the Bordeaux Guesdists formed an open alliance with the Boulangists. ${ }^{9}$

Lavigne defended this tactic in a long letter to Guesde written in early July. "Il y a trop longtemps", he declared, "que les socialistes sont dupes de leur rectitude politique." The party should not be

1 Ibid., p. 174.

2 The quotation is in a letter from Engels to Lafargue, ibid., p. 139. Italics in the original.

Ibid., p. 183.

- Laura Lafargue cautioned Engels not to mistake her husband's position for that of the Parti ouvrier. See Correspondance, II, p. 192. The police, who watched the socialists carefully on their attitude toward Boulanger, reported no dispute among Guesdist leaders in Paris. See "Attitude des socialistes devant le mouvement boulangiste", loc. cit.

5 Hutton, "Impact of the Boulangist Crisis", loc. cit., passim.

- AD Gironde, 1 M 391 (reports of 2 and 6 June 1887).

"Hutton, "Impact of the Boulangist Crisis", p. 239; AD Gironde, 1 M 391 (reports of 29 September 1888 and 9 February 1889).

8 AD Gironde, 1 M 391 (report of 18 February 1889).

- AD Gironde, 1 M 391 (reports of 27 February and 18 April 1889). 
restricted to a single tactic based on "principle", but local groups should be given room to maneuver. And he cited the instance of Guesdists in Cette allying with Republicans against Boulangists to get elected as an equally fruitful method. Only by adopting a tactical flexibility that was responsive to local political realities could the Guesdists become "a political party to be reckoned with". Any other policy, Lavigne concluded, was "suicide". ${ }^{1}$ Guesde's reply warned that Lavigne's tactics would destroy party unity, and reaffirmed in fairly standard terms the necessity for the Parti ouvrier to maintain a politics based on the class struggle, avoiding entanglement in the shifting coalitions of republican politics. ${ }^{2}$ The rebuke was mild; there is no indication either in Guesd $\epsilon$ 's letter or elsewhere that the national leaders of the party sought to discipline the mavericks in Bordeaux.

Meanwhile the Blanquists were having their own difficulties with the General. The initial position adopted by the group was essentially the same as the one formulated by Guesde in early 1888. Vaillant cooperated with the Guesdists to form a "revolutionary socialist coalition", which opposed both republican and Boulangist candidates in the Paris by-election of January $1889 . .^{3}$ Nevertheless, as with the Guesdists, there were early indications of disagreement within the ranks. At Lyon, according to a police estimate of October 1888, the Blanquists were assez Boulangistes and would vote for the General "not exactly for him but against the government"." In Paris, the future of the Comité révolutionnaire central was thrown into question by the death of Eudes on August 5, 1888, and the succession rivalry between Vaillant and Granger it produced. Granger tended toward "socialist revisionism", that is, toward a policy of alliance with Boulanger "in an idiom that was at once anti-parliamentary, nationalist and egalitarian", 5 while Vaillant favored maintenance of the revolutionary socialist alliance with the Guesdists. One element impelling Blanquists toward Boulanger was the presence in his camp of several leftists whose style of politics was similar to that of the CRC. The chief of these was Henri Rochefort, editor of L'Intransigeant,

1 Lavigne to Guesde, 8 July 1889, Guesde Archives, Internationaal Instituut voor Sociale Geschiedenis, Amsterdam.

${ }^{2}$ Draft letter of Guesde to Lavigne, undated (but presumably July 1889), Gruesde Archives.

${ }^{3}$ It is interesting to note that the coalition's candidate, the Blanquist Boule, later appeared as a "socialist-revisionist" (i.e., Boulangist) candidate in the Paris municipal elections of 1890.

4 AD Rhône, 4 M 82 (report of 3 October 1888). Further reports indicate continued support for Boulanger among Blanquists, even after his flight from the country in April 1889, 4 M 82 (report of 13 April 1889).

s Hutton, "Impact of the Boulangist Crisis", p. 228. 
which became something like the official organ of "socialist revisionism". Rochefort had considerable influence among Blanquists, and is credited with persuading a number of them to join the Boulangist camp. ${ }^{1}$ The division within the Comite came to a head in the summer of 1889 over the issue of whether the Blanquists ought to support Rochefort in the legislative elections or stand their own candidate against him. The Comité split right down the middle: Granger, Ernest Roche and the Boulangists departed, leaving Vaillant at the head of the faction that remained loyal to the "ni Ferry, ni Boulanger" formula and cooperation with the Guesdists.

As the September legislative elections approached, the socialist camp was in disarray. The Possibilists had become part of the antiBoulangist coalition, but not without misgivings on the part of some. In the Parti ouvrier discipline had been seriously breached at Bordeaux, and there were reservations elsewhere - witness Lafargue - about the wisdom of Guesde's abstentionist position. The Blanquists had just split. Regardless of the outcome of the elections, Boulanger had already left his mark on the socialist movement. Despite measures taken by the government to reduce Boulanger's chances of victory and the fact that the General had fled France six months earlier, the legislative elections were regarded in all quarters as a major test, a popular vote of confidence in the republican order. ${ }^{2}$

The election was a decisive defeat for the Boulangists. They elected only 38 deputies and their Conservative allies 167, a significant decline from the total of about 200 Conservatives elected in $1885 .^{3}$ The socialists fared even worse. On the first ballot the Possibilists ran candidates in all but three Parisian districts and in thirteen districts outside the city, many of them in the suburbs. None was elected outright, although Jules Joffrin won by default in the 18th arrondissement when Boulanger, who had actually out-polled him in that leftist stronghold by some 3,000 votes, was declared ineligible. Two Possibilists in Paris led the coalition list of republicans and thus were retained on the second ballot. Of these, one - Dumay in the 20th arrondissement - was victorious. Elsewhere Possibilists withdrew in favor of other republicans and no other party candidate was elected. ${ }^{4}$ The Guesdists and the Blanquists did no better. The Guesdists ran candidates of their own in some ten departments and supported a few other "revolutionary socialist" candidates (mostly Blanquists). They virtually abandoned Paris; their two candidates in the capital received

1 Adrien Dansette, Le Boulangisme (Paris, 1946), p. 187.

2 Seager, The Boulanger Affair, p. 233.

${ }^{3}$ Ibid., p. 236.

- For the results see Le Parti ouvrier, 24 September and 8 October 1889. 
a total of 493 votes. ${ }^{1}$ Their stronghold in the Nord produced no victories and both Guesde and Lafargue were defeated elsewhere. (That neither leader chose to run in the Nord is a significant indication of the Parti ouvrier's respect for Boulanger's strength there.) The sole Guesdist victory was that of Christophe Thivrier in the Allier. Vaillant's Blanquists elected one deputy in the Cher and another in the Rhône, but Vaillant and several others were defeated in Paris. In Bordeaux Lavigne's tactics produced one socialist deputy, Antoine Jourde. Thus a total of some eleven or twelve socialist deputies were elected, two of whom were Possibilists, one Guesdist (or two counting Jourde), and two Blanquists. The rest were Boulangist socialists or what Lafargue called "socialists in name only". ${ }^{2}$

The air had been cleared by the elections of 1889. It was obvious that the Republic had not merely survived the crisis but emerged from it strengthened. Boulangism had failed, a fact confirmed in the Paris municipal elections of April-May 1890 in which only two Boulangists were elected. ${ }^{3}$ However, the results for the socialists were little short of disastrous. The policy of republican solidarity pursued by the Possibilists had not helped the party; once the Boulangist threat was past it could no longer be justified. Indeed, after the resounding defeat of Boulanger in the elections, it was not clear that the policy of republican concentration had been justified in the first place. On the other hand, the Guesdists and the Vaillant wing of the Blanquists had utterly failed to persuade voters that the real issue was socialism, and not a choice between the Republic and its enemies. By contrast, the socialist revisionist defectors had been embarrassingly successful, although their future was uncertain. Where did the socialists go from here? The postmortems were both important and bitter.

\section{III}

In the aftermath of the 1889 elections the Possibilists returned to quarrels that had been brewing before the crisis. Between the spring of 1888 and the fall of 1889 there had been little discussion of the problems of leadership or of the weakness of the party in the provinces. Party members had pulled together in support of the policy of republican concentration. Allemane was its vociferous defender in

1 Le Temps, 24 September 1889.

2 The election results are difficult to interpret because the affiliation of some socialists is obscure. See Alexandre Zévaès, Aperçu historique sur le Parti ouvrier français (Lille, 1899), p. 102; Correspondance, II, pp. 328-35 (the quotation is from p. 334); and Daniel Ligou, Histoire du socialisme en France, 1871-1961 (Paris, 1962), pp. 108-11.

3 Seager, The Boulanger Affair, pp. 244-45. 
his journal Le Parti Ouvrier, which had been created in April 1888 as an anti-Boulangist organ with, some said, secret funds from the Ministry of the Interior. ${ }^{1}$ However, within half a year of Boulanger's defeat, apparently disillusioned and embittered by the party's performance, Allemane renewed his criticism of Brousse and other party élus. After some muted rumblings in the press, the controversy came into the open at a meeting of the Union fédérative du Centre on April 1, 1890. Here Allemane proposed that party members sitting on the Paris municipal council should, "à chaque vacance qui se produira dans le cours de leur mandat, se mettre à la disposition du Comité national, et ce dernier devra, à cet effet, organiser des tournées de conférences en province." He also called for the early convening of a national congress (there had been none in the previous year) in order "de régler d'une façon nette les devoirs des élus du Parti". There was such a furor over these proposals that no action was taken. ${ }^{2}$ Allemane next called on the party to discontinue its policy of electoral alliance with republicans and return to its revolutionary socialist program. ${ }^{3}$

In pressing the issue at this point, Allemane was looking ahead to Paris municipal elections scheduled for the end of the month. $\mathrm{He}$ feared the party would continue its alliance with republicans, an alliance he felt was compromising. Indeed, in the municipal elections, Brousse and three other Possibilists who ran without opposition from Radical or Republican candidates were elected on the first ballot and in the run-off four more Possibilists were elected, all as coalition candidates against Boulangists. ${ }^{4}$ Shortly before the elections took place Brousse was asked to explain the lack of opposition from republicans in his district. He said, according to the minutes of the meeting where the issue was raised, "qu'il a été choisi, sans être consulté, par le Comité radical [...] et que, s'étant ensuite présenté devant le Comité, il a déclaré que, quoique désigné par les républicains, il était le candidat du Parti ouvrier et qu'il se présentait aux électeurs avec le programme du Parti."5 The minutes fail to record whether Brousse's explanation was regarded as satisfactory, but it does tax one's credulity that a Radical Committee would endorse a candidate without "consulting" him. In any case, given the extent of the cooperation between Possi-

1 This was alleged by Allemane's enemies. It has been impossible to establish the truth of the charges. See Winock, "Naissance du parti 'allemaniste"”, pp. 45-46. The journal was in no way connected with the Guesdist party of the same name.

${ }^{2}$ Le Prolétariat, 12 April 1890.

3 Ibid., 5 April 1890.

4 Ibid., 3 and 10 May 1890.

Ibid., 19 April 1890. 
bilists and republicans - involving all eight of the contests in which Possibilists were elected - the independence of the party was indisputably compromised. To Allemane and a growing faction of the Union fédérative, such cooperation clearly was not justified.

After the municipal elections of late April and early May the split was in the open. On one side stood Brousse and other members of the Paris municipal council, who also dominated the party's National Committee. On the other, Allemane and his supporters in the Union fédérative. The controversy soon moved beyond a debate on substantive issues to recrimination. Brousse was denounced for his behavior in the municipal council; Allemane was criticized for his management of the party's official journal, Le Prolétariat (then experiencing difficulties). ${ }^{1}$ Lastly, the death in late May of Léo Chabert, a Paris municipal councillor and old wheel horse of the party, and the mortal illness of Jules Joffrin (who actually died in September) led to a succession struggle between the two factions.

The conflict came to a head in late August, when Allemane was removed from his position on Le Prolétariat by the Broussist-dominated cooperative society that ran it, whereupon he ceased attending meetings of the National Committee. ${ }^{2}$ Shortly thereafter, in anticipation of the party's national congress scheduled for October, the Allemanist faction hastily convened a congress of the Union fédérative $d u$ Centre. The Union fédérative congress was given over entirely to extending the control of the Union over elections and party élus at the expense of the National Committee. It bestowed upon itself the right to approve all candidates proposed by local groups or electoral committees within its jurisdiction and to resolve conflicts over the choice of candidates. No candidate was to be endorsed until he had given a signed, undated resignation to the executive committee of the Union fédérative. Candidates were to be subjected to strict control, both in their campaigns and, if elected, in office. ${ }^{3}$ This was a clear challenge to both the policies and the authority of the National Committee, a virtual declaration of independence by the Union fédérative.

Amid denunciations of these resolutions, the national congress of the Possibilists opened at Chattellerault (Vienne), remote from the centers of Allemanist strength in the Ardennes and Paris. There was no hope that the differences between the two factions could be resolved and, in fact then, little point to holding the congress. The Broussist faction,

${ }^{1}$ It may be followed in the pages of Le Prolétariat and Le Parti ouvrier (which Allemane revived in May 1890).

2 Le Prolétariat, 6 September 1890.

${ }^{3}$ For reports on the congress and texts of the resolutions adopted see Le Parti ouvrier, 7 October 1890, and Le Proletariat, 11 October 1890. 
because the National Committee had organized the congress, enjoyed an initial procedural advantage, which it employed to refuse to seat Allemanist delegates from the Ardennes on a technicality. ${ }^{1}$ When a motion to seat the delegates in spite of the irregularity was voted down, the Allemanists walked out. In the division of forces, the Allemanists seem to have come out ahead, taking with them the bulk of the organizations in Paris as well as the Ardennes federation. ${ }^{2}$ The split was followed by another round of mutual recrimination as well as intense rivalry in several Paris by-elections held in late 1890 and early $1891 .^{3}$ The schism, in short, was both bitter and definitive.

This was the shipwreck of Possibilism. The Broussists after 1890 confined their activities almost exclusively to Paris, and even within this limited arena their influence declined. In the legislative elections of 1893 they elected only two deputies despite the substantial gains made by other socialists, especially reformists, in that year. Their representation on the municipal council of Paris also fell, and the party organization atrophied. They were unable to recruit new leaders, despite the gaps opened by the departure of Allemane and the deaths of Joffrin and Chabert; talented young reformists gravitated to the Independent Socialists rather than the Broussists. With these developments, it is generally conceded, the Broussists ceased to be a serious force within French socialism. ${ }^{4}$

The Allemanists, by contrast, created in their Parti ouvrier socialiste révolutionnaire a dynamic organization that extended its influence in both Paris and the provinces. But the Allemanists departed significantly from the policies of Possibilism as those had solidified by the end of the 1880 's. They reaffirmed the class struggle as the basis of socialist

1 The mandates of the delegates from the Ardennes were held to be invalid because they were signed by the secretary of the departmental federation rather than by the secretaries of individual groups, Le Prolétariat, 18 October 1890. Le Temps, 14 October 1890 , reported that the irregularity did not prevent the National Committee from accepting 100 francs in dues from the Ardennes groups.

${ }^{2}$ A police report of 22 October 1890 (APP, B A/1480) listed 45 groups loyal to Brousse and 213 that supported Allemane. A subsequent report (13 December 1890) attributed a more realistic 75 groups to the Allemanists while leaving the Broussist strength about the same. The compte-rendu of the congress as printed in Le Proletariat did not indicate the number of delegates who stayed or departed. See also Winock, "Naissance du parti 'allemaniste"', pp. 58-59, for another assessment of Allemanist strength.

3 See Le Prolétariat, 15 November and 22 December 1890; Le Temps, 29 October $1890 ;$ APP, B A/202 (report of 1 February 1891).

- This is the view of Stafford, From Anarchism to Reformism, pp. 240-42, as well as of the writers of general histories of French socialism such as Ligou and Lefranc. 
politics, expressed serious reservations about the efficacy of parliamentarism, and shifted their orientation from electoral politics toward syndicalism. ${ }^{1}$

This two-fold development - the decline into insignificance of the Broussists and the renewed militancy of the Allemanists - removed from the national scene the one organized party that stood for reformist and parliamentary socialism. The Possibilists, moreover, had been the chief rivals of the Guesdists since 1882, and that rivalry, approximately if imperfectly defined as one between reformist and revolutionary socialism, had done much to shape the history of socialism in the 1880 's. Guesdists and Possibilists tended to define themselves in contradistinction to each other, producing in each an inflexibility of doctrine and policy that was otherwise unwarranted. The eclipse of Possibilism broke this pattern, and was therefore a major factor in permitting the opening up of socialist politics that occurred in the early 1890's, most notably for the Parti ouvrier. The demise of Possibilism was a very real victory for the Guesdists - not in the sense that they were responsible for it, but in the sense that they were the chief gainers.

Although he had lamented the failure of the Parti ouvrier in the elections of 1889 , Lafargue stoutly maintained that the party was rapidly growing in strength, and his assessment is confirmed by other sources. Growth continued in the early 1890's. Undaunted by electoral defeat, the Guesdists launched a major organizational drive in 1890 and 1891. May Day agitation in favor of the eight-hour day provided one special focus for this activity. The party's press for these years is filled with reports of the formation of new groups and of the renewed vitality of existing ones. ${ }^{2}$ Guesde in particular devoted his energies to this organizational work, making numerous trips to provincial centers. According to Williard, the party had some 2,000 members in 1889 ; by the end of 1890 it had 6,000 and by $189310,000 .^{3}$

In addition to the raw increase in the numbers of groups and individuals who supported the party, the organization was consolidated.

\footnotetext{
1 This new orientation was clearly in evidence at the POSR's first national congress held in Paris in 1891. On electoral politics the congress resolved that "the presentation of candidates for election can only be considered as a means of agitation toward an end that must be rigorously revolutionary". A resolution in favor of the general strike was also adopted. See Parti ouvrier socialiste révolutionnaire, Compte-rendu du Xe Congrès national tenu à Paris du 21 au 29 juin 1891 (Paris, 1892), pp. 100-01.

2 See particularly Le Socialiste and Le Cri du Travailleur for these years.

${ }^{3}$ The figures for 1889 and 1893 are from Willard, Le mouvement socialiste, pp. 41 and 84 ; the figure for 1890 is from a police report which says that Guesde had signed more than 6,000 membership cards by the end of that year. APP, B A/202 (report of 4 December 1890).
} 
At the national congress held in Lille in October 1890 a new set of bylaws was adopted. It established a National Council of seven members with two secretaries (invariably Guesde and Lafargue), who were responsible for managing day to day activities. Local groups and federations were also to appoint secretaries to maintain communications with the National Council. Finally, a regular system of dues collection was established. ${ }^{1}$ These measures were supplemented by a restructuring of the Party at the local and departmental level. Where possible, departmental federations were created and local groups organized on a geographic basis. This was done in the departments of Allier, Gironde, Nord and Rhône (and possibly elsewhere) in the early 1890's. ${ }^{2}$ After years of difficulty in maintaining a periodic press the Guesdists acquired a print shop in Lille in 1889. From this establishment - the Imprimerie ouvrière - issued Le Socialiste, the party's official organ, a number of provincial weeklies and a substantial assortment of brochures, campaign literature and the like. Distribution of this literature to party members on a regular basis did much to tie the party together and give its various local groups a sense of common purpose.

By these various means the Parti ouvrier acquired a degree of strength and cohesion that gave it an undisputed ascendency in the socialist movement. Guesde, in commenting on the accomplishments of the Lille Congress, declared that "the apparatus of the party is today complete. It only remains to put it to work."3 But put it to work doing what?

It was at this juncture that the German Social Democratic Party became a model for the leaders of the Parti ouvrier. Lafargue, of course, had long been familiar in a general way with the activities of the German party by means of his correspondence with Engels, and there were occasional reports in the Guesdist press on "the comrades across the Rhine". But the first serious contact between the French and the German party leaders had come in 1889 at the Paris congress that founded the Second International. From that point on the Guesdists paid close attention to the Social Democrats. When, in the Reichstag elections of February-March, 1890, the Social Democrats polled more

1 For the text of the new by-laws see Huitième Congrès national du Parti ouvrier tenu à Lille le samedi 11 et dimanche 12 octobre 1890 (Lille, 1890), pp. 24-27.

2 Willard, Le Mouvement socialiste, p. 95; Robert P. Baker, "A Regional Study of Working-Class Organization in France: Socialism in the Nord, 1870-1924" (unpublished doctoral dissertation, Stanford University, 1966), p. 52; AD Rhône, 4 M 196 (report of 27 September 1890); Hutton, "Impact of the Boulangist Crisis", p. 243.

${ }^{3}$ Le Socialiste, 2 November 1890. 
than 1.4 million votes and elected 35 deputies, their victory was loudly acclaimed by the Guesdists. ${ }^{1}$ Later in the same year, just after the Lille Congress, Guesde and two other party leaders attended the Halle Congress of the Social Democrats. They came away mightily impressed. ${ }^{2}$ During this period Deville quietly advocated that the party adopt a more moderate and pragmatic electoral policy in imitation of the Germans. Criticized for his lack of militancy by elements of the party in Paris and believing he had been unsuccessful in winning Guesde over to his point of view, Deville withdrew from active participation in party affairs. ${ }^{3}$ In a letter to Liebknecht he explained his disagreement with Guesde this way: "Guesde vous [i.e., the Social Democrats] approuve entièrement mais il trouve sans cesse des motifs pour agir autrement que vous; moi, je vous approuve entièrement et je voudrais agir ici comme vous agissez chez vous." 4 His position was set forth in an article $Z u r$ Frage der Taktik in Die Neue Zeit, ${ }^{5}$ but he refused to make a public issue of it in France.

Deville's belief that he had not convinced Guesde seems to have been in error, for there is clear evidence from police sources of the party's growing moderation after 1890. As early as May of that year an informer noticed that "le parti socialiste révolutionnaire en France fait une sorte d'évolution, qui lui fait imiter la campagne poursuivie par les socialistes allemands. C'est ainsi que J. Guesde a banni du Combat le révolutionnairisme $[\ldots]$. C'est une transformation totale de tactique". ${ }^{6}$ Later, at the time of the Lille Congress, an agent reported that "the evolution that has been made toward concentration on electoral politics can and will continue".? The new stance of the party was noticed by the bourgeois press as well, and the Guesdists felt obliged to defend themselves against the charge that they had become reformists. They were employing "new tactics", they said, but adhered to the "same principles". ${ }^{8}$

I Guesde delivered an address on 1 April 1890 on "Socialist Germany, its History, Aims and Methods" (according to Compère-Morel, Jules Guesde, p. 353). See also Le Cri du Travailleur, 9 March 1890.

2 Correspondance, II, p. 437; APP, B A/1484 (report of 28 October 1890); and Le Socialiste, 9 November 1890.

${ }^{3}$ APP, B A/202 (report of 6 December 1889) and A/1484 (reports of 11 and 18 October 1889 ).

${ }^{4}$ Deville to Liebknecht, 9 December 1890, Liebknecht Archives, Internationaal Instituut voor Sociale Geschiedenis.

5 Die Neue Zeit, IX, 1 (1890-91), pp. 478-82.

- APP, B A/201 (report of 19 May 1890). Combat was a newspaper for which Guesde wrote before the revival of Le Socialiste in September 1890.

7 APP, B A/40 (report of 8 October 1890).

8 An article entitled "Nouvelle tactique, mêmes principes", by Charles Bonnier appeared in Le Socialiste, 28 September 1890. 
It is evident that the Parti ouvrier began in 1890 to concentrate its efforts on electoral politics. From this, during the next years, flowed the adoption of a program of municipal reform, an agrarian program, cooperation for electoral purposes with other socialist and non-socialist groups, affirmations of the party's patriotism, and the various other developments of the early 1890's that were part of the party's reorientation. The transformation was effected without great internal discord. An element headed by Camescasse raised objections to the new course in the party's Agglomération parisienne, but there is evidence that Camescasse was a police agent and his motives in protesting the new line are consequently suspect. ${ }^{1}$ Otherwise, I have found no evidence that the new line was resisted in any serious way. Manifestly, it had the full support of Guesde, Deville to the contrary notwithstanding.

While the example of German Social Democracy played a significant role in demonstrating to the Guesdists the potential benefits of moderate tactics directed at electoral victories, the factors examined earlier are also important. First, there was pressure from within the party - independent of the example of Social Democracy - to exploit immediate political circumstances in order to get candidates elected. This position had been forcefully advocated by Lavigne, and the fact that in 1889 he got as many candidates elected in Bordeaux (one) as the rest of the party did elsewhere was evidence of the effectiveness, if not the virtue, of his policy. Secondly, the divisions of the Possibilists and the Blanquists combined with the growth and consolidation of the Guesdist organization gave the Parti ouvrier an ascendency in the French socialist movement it had never before enjoyed. But if the Guesdists were to preserve this ascendency, they needed to increase their electoral strength and establish a position for themselves in the arena of national politics.

Finally, the consolidation of the republican regime after the defeat of Boulanger suggested the beginning of an era of political stability, in which "the conquest of political power" could be more readily pursued at the polls than in the streets. Guesde said something very like this on the eve of the municipal elections of 1892. The time is past, he declared, when the workers could be satisfied to sit back and await the revolution. "They have learned that the Revolution is within themselves, that it will not take place - cannot take place - until they have achieved political power." He did not go so far as to say that the conquest of political power could be achieved solely at the polls, but the emphasis

1 A police report of 29 August 1891 related that Camescasse had come under suspicion and was on the verge of being discovered, APP, B A/1484. Later in the year he resigned his position on the National Council, ibid., report of 8 December 1891. 
here as elsewhere was on the importance, for the moment at least, of electoral politics. ${ }^{1}$

Compared to the Possibilists and the Blanquists, the Guesdists emerged after 1890 relatively unscathed. The fact of Boulanger's defeat aided them in this respect, for it left both pro-Boulangist and antiBoulangist socialists in something of a muddle. The former needed to find a new home once it was clear, as certainly it was by 1890 , that Boulangism was finished. The latter could no longer justify republican concentration against Boulanger. Thus the Guesdists were in a good position to appropriate for themselves the element of social protest contained in the movement, and they did so by accepting Boulangist socialists into their ranks. Both Jourde, Lavigne's successful candidate in Bordeaux, and Joseph Ferroul, dubbed by Lafargue a socialist in name only and elected with Boulangist support in Narbonne, were accepted without protest. ${ }^{2}$ Ferroul was even elected to the National Council of the Parti ouvrier in 1890. But the most important factor in the situation was that open quarrels did not disrupt the Parti ouvrier. This permitted it to move ahead vigorously in the early 1890's, winning new recruits and consolidating its organization, at precisely the moment when Possibilists and Blanquists were racked with schism.

\section{IV}

The combination of events here described produced a major change in the pattern of French socialist politics. Where there had been in the 1880 's three autonomous organizations with off-setting strengths and weaknesses, now the Parti ouvrier emerged as the dominant organization, with Vaillant's small group of Blanquists as allies. Its old rivals the Broussists were in eclipse, and the Allemanists had adopted a new militancy strongly colored by syndicalism. The Guesdists were thus presented with an opportunity that was partly of their own making (their plodding but effective organizational work, chiefly), partly also the consequence of political developments over which they had no control. It is of course a moot question whether Possibilists and Blanquists would have fallen prey to division in the absence of the Boulanger Crisis. The basic issues arose independently and were present by 1888 , but the pace at which the conflicts developed to the point of schism was surely affected by the Crisis. This is an important point, for had

${ }^{1}$ Le Socialiste, 23 April 1892. See also Guesde's "Réponse ouverte" to Pelloutier in Le Socialiste, 16 October 1892.

2 Except from Engels, who complained to Lafargue that the Parti ouvrier was going too far in welcoming erstwhile Boulangists into its ranks. See Correspondance, II, p. 346. 
the two schisms not occurred in such close proximity to one another, the Guesdists would not have been left in such clear domination of the field.

It seems to me that the Guesdists' much discussed reformism of the early 1890's - the emphasis on electoral politics, municipal and agrarian programs, the affirmations of patriotism and of the commitment to peaceful methods - must be understood as a response to their new situation. ${ }^{1}$ With the Broussists reduced to insignificance, the Guesdists were no longer compelled to define their position as the antithesis of the reformist socialism Brousse represented. Thus only after 1890 could they develop a municipal socialism and engage in electoral politics without jeopardizing their separate identity. This, plus their expanded membership, the example of the German Social Democrats and independent pressures from within the party combined to push them toward greater moderation and flexibility. But this occurred in a context in which the Guesdists enjoyed an advantage over their ancient rivals, and they sought to exploit that advantage to dominate the French socialist movement and to make the Parti ouvrier the umbrella organization of a comprehensive social democracy. ${ }^{2}$ However, this does not mean that the Guesdists underwent any basic transformation of outlook. Their most sympathetic historian of recent years has drawn attention to the superficiality of the change in Guesdist tactics in the early 1890's, noting that because it did not involve any change in theoretical position it produced a kind of schizophrenia in Guesdism between theory and practice. ${ }^{3}$ What we have, then, is a political reorientation, marked by shifts in the relative strength of various groups and by the efforts of the Guesdists to exploit their advantage, rather than any basic transformation, if by that is understood a thorough re-examination of the role of socialism in the politics of the Republic.

\footnotetext{
1 See the article by Leslie Derfler, "Reformism and Jules Guesde, 1891-1904", in: International Review of Social History, XI (1967), pp. 66-80. Derfler focuses on Guesde alone without taking into consideration the more general situation of the Parti ouvrier. His conclusion that Guesde first embraced and later rejected reformist tactics largely in order to maintain "his position of authority" is scarcely adequate to explain the behavior of the entire party.

2 A thorough analysis of the Guesdist bid for domination of the socialist movement in the early 1890's would require a study as lengthy as the present one. Certainly they were encouraged in this direction by the example of the German Social Democrats and directly by Engels. In addition to their new electoral programs and tactics, one can cite their appeal for support from Allemanists and their attempt to dominate the labor movement through the Fédération nationale des syndicats as parts of this effort.
}

3 Willard, Le Mouvement socialiste, pp. 213-15, 597-98. 